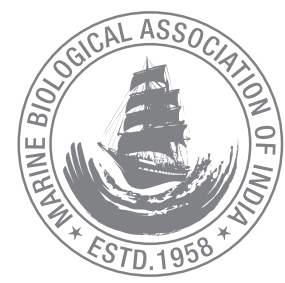

\title{
Effect of low temperature on the survival of edible oyster Crassostrea madrasensis during transportation and storage
}

\author{
S. Chinnadurai *, V. Kripa, V. Venkatesan, and K. S. Mohamed \\ *Molluscan Fisheries Division, Central Marine Fisheries Research Institute, PB No. 1603, Cochin, Kerala State, 682018 \\ India. \\ *Correspondence e-mail: chinnaduraitvl@gmail.com
}

Received: 12 Sept 2013, Accepted: 03 Dec 2013, Published: 20 Dec 2013

\begin{abstract}
The survival of the tropical edible oyster (Crassostrea madrasensis) was examined under the condition of ice-storage in a rectangular thermocol-transport box for a period of $48 \mathrm{~h}$. A total of 100 two-year old farmed oysters were used for the experimental transportation. Inside the box, all oysters were arranged in four layers covered with wet-gunny bags and lined on the top and bottom with ice. Surface and bottom temperature of the transport box varied from 9.7 to $25.2^{\circ} \mathrm{C}$ and 9.7 to $28.4^{\circ} \mathrm{C}$ respectively during the $48 \mathrm{~h}$ exposure. The patterns of changing temperature at both surface and bottom were found to be different. Recoveries of the oysters at every two hours till $48 \mathrm{~h}$ were monitored by taking random samples from the box. All the oysters recovered within $1 \mathrm{~h}$ of being placed back into seawater and there was close to $100 \%$ recovery within 2 hours. Survival was more than $90 \%$ after 8 days of the experiment.
\end{abstract}

Keywords: Low temperature, survival, edible oyster, transportation.

\section{Introduction}

Oyster is very rich in protein and minerals and is generally sold with shell-on and consumed fresh throughout the world. Eating oyster in raw form is good for health because cooking reduces the quantity of amino acids. Most oysters produced in the UK are distributed live and are frequently eaten raw or sometimes lightly cooked (Stroud, 1981). In India, edible oyster, Crassostrea madrasensis farming is being practiced by several farmers, especially women Self-Help Groups in central Kerala employing the rack and ren method in the estuaries and backwaters. However, farmed oysters do not find ready market acceptability and good price. After introduction of depuration system for high-end restaurants through the National Agriculture Innovative Project (Mohamed et al., 2011), consumer confidence in the product has increased and thereby, rate per live oyster has increased from Rs. 1 to Rs. 7.5. Thus, the live oyster value chain has been developed in the city of Kochi and has great scope to expand to other metro cities (Mohamed and Kripa, 2013). The estimated production of farmed oysters from India in 2010 is 3200 tonnes (FA0, 2012). It is generally understood that to maintain a high survival rate and good meat quality throughout storage, one must pay careful attention to many factors including condition of the oysters, packaging, humidity and temperature. If the live value chain has to expand in other cities, there is a need for long distance transportation of live oysters and for its survival in a display unit or tank. Although few relevant studies have been carried out (Rajapandian and Muthiah, 1987; Samuel et al., 1987), no information about the storage condition and survival of edible oysters in the transport box during long distance transportation are available. Therefore, the aim of the present study was 
to test the effect of low temperature on the survival of the live oyster during long distance transportation and thereafter its recovery period in tank and thereby to evolve an effective live oyster transport protocol.

\section{Material and methods}

A total of 100 two year old farmed depurated oysters were used in the present experiment. The oysters were collected from a Sathar Island oyster farm, brushed clean of all epibionts, kept moist and used for the experiment within 6 hours. Experiments were undertaken at the Edible Oyster Hatchery of Central Marine Fisheries Research Institute, at Narakkal, Kochi, India. The mean length, width, depth and weight of the oysters were $69.96 \mathrm{~mm}, 54.95 \mathrm{~mm}, 28.17 \mathrm{~mm}$, and 61 $\mathrm{g}$ respectively. Oysters were kept in a rectangular thermocol box $50 \times 30 \times 35 \mathrm{~cm}$, with total volume of 30 litre. 100 oysters were placed in four vertical layers (i.e., 25 oysters in each) and covered with a wet gunny (jute) bag (Fig.1) at the top and bottom. The box was packed with ice at the top and bottom at a thickness of $5 \mathrm{~cm}$ and perforated thermocol sheets were

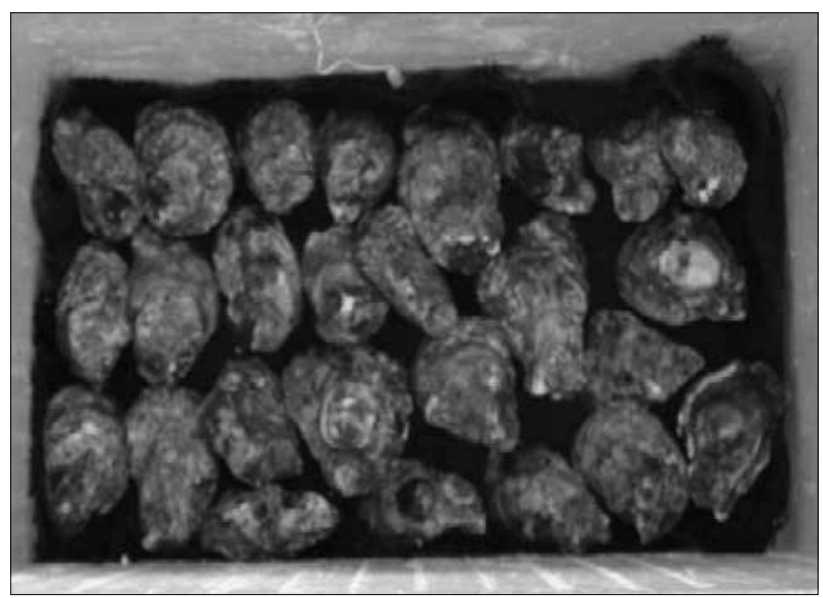

Fig 1. Oysters placed on wet gunny bag arranged in the thermocol box

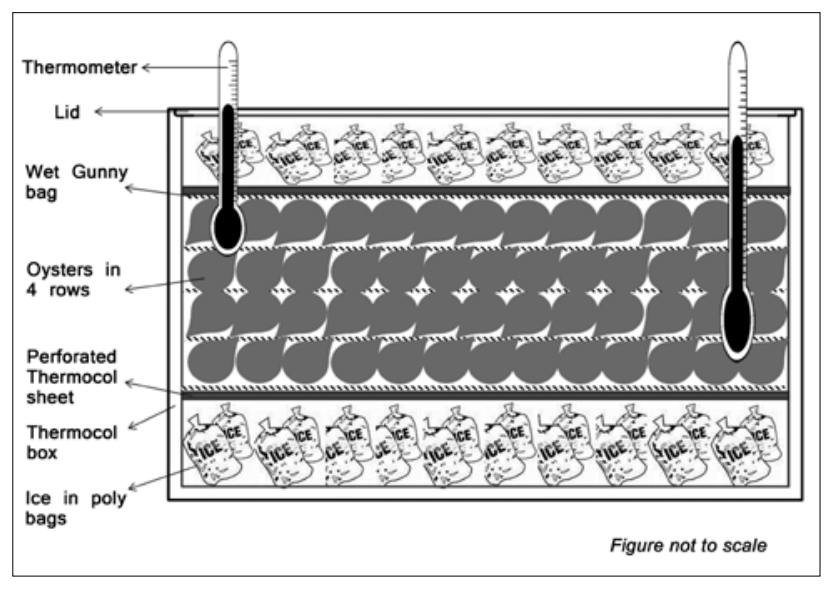

Fig 2. Cross section of rectangular thermocol-transport box with oysters
Table 1. Temperature recordings in the experimental box containing oysters and their recovery percentage.

\begin{tabular}{|c|c|c|c|c|}
\hline Time & Temperature $\left({ }^{\circ} \mathrm{C}\right)$ & & & \\
\hline (h) & Surface & Bottom & Recovery (\%) & $\begin{array}{l}\text { Time taken for } \\
\text { recovery (mins) }\end{array}$ \\
\hline 00 & 15.8 & 28.4 & - & - \\
\hline 02 & 15.5 & 28.0 & 100 & 2 \\
\hline 04 & 14.7 & 21.3 & 100 & 2 \\
\hline 06 & 13.5 & 16.7 & 100 & 2 \\
\hline 08 & 11.1 & 13.5 & 100 & 2 \\
\hline 10 & 09.7 & 10.9 & 100 & 2 \\
\hline 12 & 13.4 & 09.9 & 100 & 3 \\
\hline 14 & 13.9 & 09.7 & 100 & 3 \\
\hline 16 & 14.0 & 10.0 & 100 & 3 \\
\hline 18 & 15.6 & 10.8 & 100 & 3 \\
\hline 20 & 17.0 & 12.1 & 100 & 3 \\
\hline 22 & 17.8 & 13.7 & 100 & 5 \\
\hline 24 & 19.2 & 16.1 & 100 & 5 \\
\hline 26 & 19.4 & 17.9 & 100 & 5 \\
\hline 28 & 20.8 & 19.3 & 100 & 5 \\
\hline 30 & 21.3 & 19.6 & 100 & 5 \\
\hline 32 & 21.9 & 20.1 & 100 & 5 \\
\hline 34 & 22.7 & 21.7 & 100 & 6 \\
\hline 36 & 23.0 & 23.2 & 100 & 6 \\
\hline 38 & 23.6 & 24.0 & 100 & 8 \\
\hline 40 & 23.6 & 24.8 & 100 & 8 \\
\hline 42 & 23.9 & 25.1 & 100 & 8 \\
\hline 44 & 24.0 & 25.3 & 100 & 9 \\
\hline 46 & 24.6 & 25.5 & 100 & 11 \\
\hline 48 & 25.2 & 25.7 & 100 & 11 \\
\hline
\end{tabular}

placed at both ends in order to avoid direct contact of oysters with ice (Fig.2).

The ice packs used in the experiment were prepared by using freshwater, which was packed in polythene zip-lock covers and placed in deep freezer. The polythene cover was used to curtail the leaking of melted water. Two thermometers were placed at both ends of the box for measuring temperature at the surface and bottom of the oyster layers respectively at an interval of two hours. Two oysters were taken from the box at every two hours and placed in a tank containing filtered seawater for monitoring continually their recovery. Recovery in oyster was defined as the length of time between release and the closure of animal shells in response to touching of their mantle tissue (Norton et al., 1996). This experiment was continued up to 48 hours after which all the oysters were 
returned to a tank with filtered seawater, and provided with cultured diatom as feed and monitored daily (upto 8 days) for survival.

\section{Results and discussion}

Table 1 shows the surface and bottom temperature of the experimental box containing oysters and their recovery (at every two hours) and the time taken for it. The patterns of temperature at surface and bottom of the box containing oysters were different. Surface temperature gradually decreased from the inception $\left(15.8^{\circ} \mathrm{C} ; 00 \mathrm{~h}\right)$ onwards and reached the minimum at $10 \mathrm{~h}\left(9.7^{\circ} \mathrm{C}\right)$. Thereafter, it increased steadily and reached the maximum at the conclusion of experiment $\left(25.2^{\circ} \mathrm{C} ; 48 \mathrm{~h}\right)$. Bottom temperature of the box ranged between 9.7 to $28.4^{\circ} \mathrm{C}$ with the minimum seen in $14 \mathrm{~h}$ and maximum observed at the beginning of the experiment. Bottom temperature decreased steadily from $28.4^{\circ} \mathrm{C}$ at the beginning and reached the minimum at $14 \mathrm{~h}\left(9.7^{\circ} \mathrm{C}\right)$. Thereafter, it increased gradually to the termination of the experiment $\left(25.7^{\circ} \mathrm{C} ; 48 \mathrm{~h}\right)$. The temperature fluctuations were within the optimal range and sufficient for the survival of oysters with a minimal stress.

Different storage temperature and conditions are required for the different species and the protocol of one species of oyster may not apply to another. For instance, Pacific oysters are transported and stored under refrigeration $\left(5^{\circ} \mathrm{C}\right)$ for maximum shelf life, while Sydney rock oysters are stored at temperatures below about $8^{\circ} \mathrm{C}$ (Bird et al., 1995). In the present study, animals were allowed to recover at every two hours (Table 1) during the entire course of the experiment. Surprisingly, all animals were found to recover well even after $48 \mathrm{~h}$. the time taken for recovery of oyster ranged from 2 minutes at the start of the experiment to 11 minutes after $48 \mathrm{~h}$. Keeping oysters in moist and cool conditions has probably aided their recovery as also observed by Stroud (1981) in European oyster Ostrea edulis and Pacific oyster Crassostrea gigas. Stroud, (1981) based on his studies in the handling and processing oysters in Aberdeen, Scotland stated that oysters can survive out of water for weeks, if carefully handled and kept cool and moist by covering with a damp cloth. He further stated that oysters should be carried with the cupped half of the shell downwards and the edge of the shells should not be damaged since they will rapidly lose liquid from within.

Oyster can survive at water temperatures as low as $-2^{\circ} \mathrm{C}$ and as high as $49^{\circ} \mathrm{C}$; Survival at either temperature extreme increases when the oysters are covered with waters (Harding et al., 1999). Temperature is the most important exogenous factor regulating the metabolism of exothermic organisms and its influence on the rates of oxygen consumption, feeding
Table 2. Survival of the oysters after the experimentation

\begin{tabular}{lll}
\hline Number of & Number of & Mortality \\
\hline days & oysters & $(\%)$ \\
\hline 1 & 52 & Nil \\
\hline 2 & 52 & Nil \\
\hline 3 & 52 & Nil \\
\hline 4 & 52 & Nil \\
\hline 5 & 50 & 3.8 \\
\hline 6 & 47 & 6.0 \\
\hline 7 & 47 & Nil \\
\hline 8 & 47 & Nil \\
\hline
\end{tabular}

and nitrogen excretion in temperate species of bivalves has been studied extensively (Newell and Bayne, 1980; Bayne and Newell, 1983). Because oyster metabolism is directly correlated with water temperatures, temperatures affect every aspect of oyster biology including reproduction, larval success, settlement, feeding, growth and development. At very low and very high temperatures, oyster metabolic rates decrease to maintenance levels. At intermediate or "normal" temperatures, oyster metabolic rates increase seasonally enabling growth and reproduction.

Survival of the oysters of the box was monitored visually in a tank after the experiment for 8 days (Table 2). No mortality was observed in animals (52 numbers) upto 4 days. Thereafter, 5 animals were found dead during 5 th and 6th days (nearly $10 \%$ mortality). It can be concluded that live oysters can be safely transported for a period of $48 \mathrm{~h}$ with $90 \%$ survival. Pacific oysters (Crassostrea gigas) stored in air with water sprinkling at $7^{\circ} \mathrm{C}$ had $52-80 \%$ of survival after 20 weeks storage (Seaman, 1991). Samuel et al. (1987) have reported a mortality rate of $0.45 \%$ when live oysters were transported and stored without seawater upto $24 \mathrm{~h}$ at ambient temperature. Similar observations were made by Rajapandian and Muthiah (1987) when live oysters were transported from Tuticorin. The percentage of mortality (10\%) observed in the present study is more compared to that observed earlier. This may be because the earlier observations were limited to recovery of oysters after transportation not the survival upto 8 days as observed in the present study and also the duration of transportation is half compared to the present experiment. They had also moistened the gunny bag containing oysters with seawater frequently throughout the journey by road and also drained the excess water at frequent intervals. However, the present protocol is recommended since the oysters have high survival even after 8 days. These oysters can also be used in high-end restaurants where depuration facilities are available. 


\section{Acknowledgements}

The study was funded by National Agricultural Innovation Project (NAIP) of the ICAR and World Bank which is gratefully acknowledged. The authors are grateful to the Director, Central Marine Fisheries Research Institute (CMFRI), Kochi for facilities and encouragements.

\section{References}

Bayne, B. L., and R. C. Newell. 1983. Physiological energetics of marine molluscs. In: Saleuddin, A. S. M., Wilbur. K. M. (eds.) The Mollusca, Vol. 4, Physiology, Part 1. Academic Press, New York. p. 407-515

Bird, P. D., A. J. Glenda, J. Holliday, and A. Boronowsky.1995. Effect of storage on the quality of purified live Pacific and Sydney rock oysters. Conference Internationale sur la Purification des Coquillages.Rennes (France), archimer.ifremer: $n^{\circ} 1624$, 315-322

FAO. 2012. Fish Stat-Universal software for fishery statistical time series. FAO, Rome. Harding, T. M., R. Mann, V. P. Clark. 1999. Oyster reef communities in the Chesapeake Bay: A brief primer. Virginia Institute of Marine Science. Gloucester point, VA. VSG-99-05, VIMS-ES-44 4/99.
Mohamed, K.S., V. Kripa, T.S. Velayudhan, Mathew Joseph, B. Jenni, P.S. Alloycious, Rakesh Sharma and N. Raveendra Durgekar. 2011. Oyster depuration display unit for high-end restaurants. NAIP Component 2 Project; A value chain on High Vlaue Shellfishes from mariculture systems.p. 1- 19.

Mohamed, K. S., and V. Kripa. 2013. Oyster farming: New hope for increasing mariculture production in India. MPEDA News letter, 22 (1): 55-57.

Newell R.I.E., and B. L. Bayne. 1980. Seasonal changes in physiology, reproductive condition and carbohydrate content of the cockle Cardium (=Cerastoderma) edule (Bivalvia: Cardiidae). Mar. Biol., 56:11-19.

Norton, J.H., M. Dashorst, T.M. Lansky, and R.J. Mayer. 1996. An evaluation of some relaxants for use with pearl oysters. Aquaculture, 144: 39-52.

Rajapandian, M.E., and P. Muthiah, 1987. Post harvest technology. National Seminar on shellfish resources and farming, 19-21, January 1987, Central Marine Fisheries Research Institute, Tuticorin.394-397.

Samuel, G.E., C. J. Jose and R. Sathiarajan. 1987. Canning of smoked oyster. Symp. Harvest and Post-Harvest Technology of fish, Cochin; 24-27, Nov., Soc. of Fisheries Technologists (India), Abs, 130.

Seaman, M. N. L. 1991. Survival and aspects of metabolism in oysters (Crassostrea gigas) during and after prolonged air storage. Aquaculture, 93: 389-395.

Stroud, G.D. 1981. Handling and processing oysters. Advisory Note No. 84.Torry Research Station, Aberdeen, Scotland, U.K., p 1-10. HMSO in Edinburgh. 